\title{
ANALISIS FINANSIAL PEMBESARAN IKAN BETUTU (Oxyeleotris marmorata Blkr) DALAM HAMPANG DI LAHAN RAWA LEBAK SUMATERA SELATAN
}

\author{
Rupawan"), Zahri Nasution") dan Zainal Arifin*)
}

\begin{abstract}
ABSTRAK
Peningkatan pemanfaatan lahan rawa lebak untuk budidaya ikan harus didukung oleh keragaan aspek teknis dan aspek ekonomi. Untuk mengetahui analisis finansial pembesaran ikan betutu dengan pemberian jenis pakan berbeda telah dilakukan penelitian selama 6 bulan menggunakan hampang di kolam lahan rawa Kertamulia Sumatera Selatan. Ukuran hampang $18 \mathrm{~m}$, sebanyak 2 unit ditebari 8 ekor/m, ikan betutu dengan rataan bobot 176,2 gram. Perlakuan pemberian pakan tambahan ikan rucah dan moluska (daging keong sawah). Pakan diberikan sebanyak 3\% dari bobot badan ikan per hari pada waktu sore hari.

Hasil penelitian menunjukkan bahwa ditinjau dari aspek ekonomi kedua perlakuan pakan tersebut cukup layak. Perlakuan pakan ikan rucah memberikan tingkat keuntungan dan efisiensi usaha yang lebih baik dibanding perlakuan pakan moluska. Keuntungan yang didapat pada perlakuan pakan rucah adalah Rp1.062.000.- dengan $\mathrm{RC}$ ratio 2,44, rentabilitas 157,5\%. Dengan jangka waktu pengembalian investasi selama 6,5 bulan atau 1,08 periode usaha.

Di lain pihak keuntungan usaha pada perlakuan pakan moluska adalah Rp802.000, RC ratio 2,11 , rentabilitas $124 \%$. Dengan jangka waktu pengembalian investasi selama 7,9 bulan atau 1,31 priode usaha. Dengan informasi analisis finansial usaha pembesaran ikan betutu sistem pen ini diharapkan akan memberikan alternatif pemanfaatan lahan rawa atau pengembangan usaha ke arah yang lebih luas.
\end{abstract}

\section{ABSTRACT: Financial Analysis of Sand Goby Pen Culture System at Swampy Area in South Sumatera. By : Rupawan, Zahri Nasution and Zainal Arifin.}

A financial analysis of an experimental culture of sand goby was conducted in Kertamulia, South Sumatera in order to assess the feasibility of fish culture in swampy area. The fish was cultured in 2 pen enclosures of $18 \mathrm{~m}^{2}$ each, stocked at a density of $8 \mathrm{fish} / \mathrm{m}$. During 6 month experimental period the fish were fed with 2 different feeds; i.e. trash fish and mollusc meat at the rate of $3 \%$ of body weight.

The result showed that rearing sand goby in pen system either fed with trash fish or mollusc meat were economically feasible. Treatment with trash fish gave a higher net profit of $\mathrm{Rp} 1,062,000$. with the $\mathrm{R} / \mathrm{C}$ ratio of 2,44 and rentability of $157,5 \%$, while in treatment with mollusc meat gave a net profit of $\mathrm{Rp} 802,000$, with the $\mathrm{R} / \mathrm{C}$ ratio of 2,11 and rentability of $124 \%$.

The findings would support the development of fish culture as an alternative use of marginal land in swampy area.

KEYWORDS: Sand Goby, swampy area, pen system, financial analysis.

\section{PENDAHULUAN}

Lahan rawa di Indonesia diperkirakan lebih kurang 33,4 juta hektar yang terdiri atas 20,1 juta hektar rawa pasang surut dan pantai serta selebihnya rawa nonpasang surut atau lebak. Berdasarkan karakternya ada 5 tipologi lahan pasang surut dan rawa, salah satu di antaranya adalah rawa lebak, yaitu lahan rawa yang dipengaruhi oleh luapan air sungai dan hujan sehingga tergenang 3-12 bulan per tahun dengan kedalaman air $50 \mathrm{~cm}$ sampai $100 \mathrm{~cm}$ atau lebih.

Rawa merupakan bagian dari perairan umum yang banyak dihuni oleh jenis-jenis ikan terutama dari kelompok labirinth. Salah satu dari jenis tersebut adalah ikan betutu yang dewasa ini

") Peneliti pada Loka Penelitian Perikanan Air Tawar Palembang 
cukup berpotensi untuk dibudidayakan karena digemari masyarakat sebagai ikan konsumsi dan merupakan salah satu komoditas ekspor sehingga mempunyai nilai ekonomi cukup tinggi (Widiyati dan Djajasewaka, 1992).

Hingga saat ini pemenuhan kebutuhan ikan betutu terutama ukuran konsumsi masih mengandalkan hasil tangkapan dari alam. Untuk itu dalam rangka meningkatkan produksi secara berkesinambungan perlu segera dilakukan kegiatan budidaya. Hal ini sekaligus menunjang pemanfaatan sumber daya perikanan perairan umum secara optimal serta dapat memecahkan masalah merosotnya hasil tangkapan di perairan umum.

Salah satu kendala dalam pengembangan dan pendayagunaan sumber daya perikanan perairan umum secara optimal adalah keterbatasan ilmu pengetahuan dan teknologi budidaya perikanan perairan umum. Sedangkan usaha penerapan teknologi budidaya perikanan perairan umum kepada masyarakat petani harus didasarkan pada beberapa pertimbangan yang bersifat menyeluruh seperti aspek teknik, ekonomi dan sosial budaya. Untuk itu penelitian harus berorientasi kepada efisiensi ekonomi tinggi di samping teknologi yang bermanfaat untuk diterapkan bagi masyarakat petani.

Budidaya ikan sistem hampang merupakan budidaya semi-intensif. Pola usaha budidaya tradisional dan semi-intensif memerlukan biaya investasi dan operasional yang relatif lebih rendah jika dibandingkan dengan pola usaha budidaya intensif. Ditinjau dari rasio keuntungan terhadap biaya operasional maka pola usaha budidaya tradisional lebih menguntungkan untuk petani kecil, sedangkan pola usaha budidaya intensif lebih memadai untuk usaha komersial dan industri (Djajadiredja dan Yunus, 1982). Biaya operasional tinggi umumnya berasal dari komponen biaya pakan (Nasution dan Utomo, 1994) sehingga perlu alternatif pakan pengganti yang memberikan pengaruh pertumbuhan relatif sama tetapi lebih murah dan mudah didapat, karena komponen biaya akan berpengaruh pada tingkat keuntungan dan efisiensi masukan.

Penelitian ini bertujuan mengetahui sejauh mana kelayakan ekonomi usaha pembesaran ikan betutu yang dipelihara dalam hampang (pen system) di kolam lahan rawa.

\section{BAHAN DAN METODE}

Penelitian dilakukan di kolam percobaan lahan rawa Patratani Palembang, Sumatera Selatan. Sebagai wadah percobaan digunakan hampang bambu ukuran $18 \mathrm{~m}^{2}$ sebanyak 2 unit. Ikan uji berasal dari hasil tangkapan di alam dengan bobot rata-rata 176,2 gram dan padat tebar $8 \mathrm{ekor} / \mathrm{m}^{2}$. Pakan diberikan sebanyak 3\% dari total bobot ikan/hari dengan perlakuan pakan ikan rucah dan pakan moluska (daging keong sawah) yang diberikan pada waktu sore hari.

Penelitian dilakukan selama 6 bulan dan setiap bulan dilakukan pengukuran bobot sampel ikan sebanyak $30 \%$ dari jumlah populasi ikan, sebagai dasar penentuan ransum pakan bulan berikutnya.

Pada akhir penelitian dilakukan pengukuran bobot total ikan untuk mengetahui produksi total masing masing perlakuan. Biaya produksi diperhitungkan berdasarkan nilai seluruh pengeluaran atau masukan yang terdiri dari biaya tetap (penyusutan hampang dan bunga investasi) dan biaya tidak tetap (benih ikan, pakan ikan dan tenaga kerja) serta nilai pendapatan diperhitungkan berdasarkan nilai produksi atau keluaran (produksi ikan x harga).

\section{Penerimaan $=$ Produksi $x$ Harga}

Analisis data dilakukan secara sederhana, yaitu indikator keuntungan usaha yang diperhitungkan dari nilai pendapatan dikurangi biaya tidak tetap atau pendapatan atas biaya tidak tetap (Wattanutchariya and Panayotou 1981).

\section{Keuntungan $=$ Penerimaan - Biaya variabel}

Efisiensi usaha dihitung berdasarkan kaidah: Return Cost Ratio (RC ratio), yaitu perbandingan antara nilai pendapatan dibagi total biaya (Soeharjo, 1972).

$$
R C \text { ratio }=\frac{\text { Pendapatan }}{\text { Biaya Total }}
$$

Rentabilitas usaha diamati dari persentase keuntungan yang didapat dibandingkan dengan modal yang dikeluarkan untuk men-dapatkan keuntungan usaha tersebut (Nitisemito, 1991).

$$
\text { Rentabilitas }=\frac{\text { Keuntungan }}{\text { Biaya Total }} \times 100 \%
$$


Nilai titik impas dan jangka waktu pengembalian investasi dihitung berdasarkan persamaan yang dikemukakan oleh Sigit (1979) dan Gitingger (1986), yaitu:

$$
\begin{gathered}
\text { Nilai titik impas }=\frac{\text { Biaya tetap }}{1-(\text { Biaya variabel }: \text { Nilai produksi })} \\
\text { Jangka waktu pengembalian investasi }=\frac{\text { Biaya total }}{\text { Keuntungan }}
\end{gathered}
$$

\section{HASIL DAN PEMBAHASAN}

\section{Produksi, Nilai Produksi dan Keuntungan Usaha}

Tingkat dan nilai produksi usaha pemeliharaan ikan betutu dalam hampang berdasarkan jenis pakan diterakan pada Table 1. Sedangkan komponen biaya, pendapatan serta keuntungan usaha dicantumkan pada Table 2.

Dari Table 1 dapat dilihat bahwa produksi dan nilai produksi perlakuan pakan ikan rucah lebih tinggi dari pada perlakuan pakan moluska.

Pada Table 2 dapat dilihat bahwa pembesaran ikan betutu dalam hampang dengan pakan tambahan ikan rucah dan moluska masing. masing dapat memberikan tingkat keuntungan usaha yang cukup besar. Perbedaan besarnya keuntungan usaha antara perlakuan pakan ikan rucah dibanding perlakuan pakan moluska disebabkan tingkat pertumbuhan dan produksi ikan yang berbeda dan jumlah biaya produksi yang relatif sama. Tingkat produksi yang lebih tinggi selanjutnya mengakibatkan nilai produksi juga lebih besar.

Table 1. Production (kg) and value $(R p)$ of sand goby production by type of feed.

\begin{tabular}{lcc}
\hline Kind of feed & $\begin{array}{c}\text { Production } \\
(\mathbf{k g})\end{array}$ & $\begin{array}{c}\text { Value } \\
(\boldsymbol{R p})\end{array}$ \\
\hline Trash fish & 66 & 1.650 .000 \\
Mollusc & 54,6 & 1.365 .000 \\
\hline
\end{tabular}

Remark: The price of sand goby at the collector was Rp 25,000/kg

Table 2. Income analysis of sand goby pen culture in Rawa Lebak, Sumatera Selatan.

\begin{tabular}{lrr}
\hline \multicolumn{1}{c}{ Item } & Trash fish & Mollusc \\
\hline 1. Fixed cost & & \\
Depreciation & 30,000 & 30,000 \\
Interest of investment & 55,600 & 53,400 \\
\cline { 2 - 3 } & 85,600 & 83,400 \\
2. Operational cost & & \\
Seed & 203,000 & 203,000 \\
Feed & 205,500 & 180,000 \\
Labour & 180,000 & 180,000 \\
& 588,500 & 563,000 \\
3. Total cost & 674,100 & 646,400 \\
4. Revenue & $1,650,500$ & $1,365,000$ \\
5. Profit (4-2) & $1,062,000$ & 802,000 \\
\hline
\end{tabular}




\section{Indikator Kelayakan Usaha}

Kelayakan ekonomi usaha pembesaran ikan betutu dalam hampang berdasarkan beberapa kriteria disajikan pada Table 3 dan 4.

Table 3 menunjukkan bahwa efisiensi usaha yang dihitung berdasarkan besarnya nilai perbandingan pendapatan dan biaya pada perlakuan pakan ikan rucah dan pakan moluska cukup baik namun lebih baik pada perlakuan pakan ikan rucah. Dikatakan cukup baik karena nilai $\mathrm{RC}$ Rasio tersebut yang lebih besar dari 1 .
Table 3 juga menunjukkan bahwa tingkat rentabi-litas perlakuan kedua jenis pakan cukup me-madai. Karena memadai atau tidaknya keuntungan pada umumnya tidak dilihat dari berapa jumlah keuntungan yang didapat tetapi berapa tingkat keuntungan atau rentabilitasnya.

Menurut Nitisemito (1991) rentabilitas dikatakan memadai bila lebih besar dari rata- rata tingkat suku bunga deposito pada waktu dan periode yang sama, dalam hal ini $12-14,5 \% /$ tahun (suku bunga deposito berjangka 6 bulan, tahun 1995).

Table 3. Return cost ratio and rentability rate of sand goby pen culture.

\begin{tabular}{lcc}
\hline Kind of feed & $\boldsymbol{R} / \boldsymbol{C}$ & Rentability \\
\hline Trash fish & 2.44 & $157,5 \%$ \\
Mollusc & 2.11 & $124,0 \%$ \\
\hline
\end{tabular}

Di samping itu, untuk mengetahui sejauh mana usaha pembesaran ikan betutu dalam hampang ini masih menguntungkan bila terjadi penurunan harga jual ikan, maka nilai titik impas pada berbagai tingkat harga jual ikan dapat menggambarkannya (Table 4).

Table 4. Break even points of sand goby pen culture based on different fish price scenario.

\begin{tabular}{lccc}
\multirow{2}{*}{ Kind of feed } & Price of fish & \multicolumn{2}{c}{ Break even point } \\
\cline { 3 - 4 } (Rp/kg) & 15,000 & in $\boldsymbol{R p}$. & in $\mathbf{K g}$ \\
\hline \multirow{2}{*}{ Trash fish } & 213,900 & 14.26 \\
& 12,000 & 342,360 & 28.53 \\
& 11,000 & 475,530 & 43.23 \\
\multirow{2}{*}{ Mollusc } & 10,250 & 658,461 & 64.24 \\
& 10,000 & 856,000 & 85.20 \\
& 15,000 & 268,950 & 17.93 \\
& 12,000 & 595,700 & 49.64 \\
& 11,750 & 683,600 & 59.17
\end{tabular}


Di samping itu, untuk mengetahui sejauh mana usaha pembesaran ikan betutu dalam hampang ini masih menguntungkan bila terjadi penurunan harga jual ikan, maka nilai titik impas pada berbagai tingkat harga jual ikan dapat menggambarkannya (Table 4).

Pada Table 4 dapat dilihat bahwa usaha pembesaran ikan betutu dalam hampang menggunakan pakan ikan rucah masih menguntungkan bila terjadi penurunan harga jual ikan sampai Rp10.250/kg. Hal ini karena sampai pada tingkat harga jual tersebut nilai break even point dalam Rupiah dan kg (Table 4) masih berada di bawah tingkat dan nilai produksi, yaitu masing-masing 66 kg dan Rp676.500,-. Sebaliknya akan merugi bila harga jual mencapai 10.000 atau lebih rendah karena mulai pada tingkat harga jual tersebut nilai break even point dalam Rupiah dan $\mathrm{Kg}$ sudah lebih besar dari tingkat dan nilai produksi masing- masing 66 kg dan Rp660.000,-

Sedangkan bila menggunakan pakan moluska masih menguntungkan bila penurunan harga jual sampai $R p 12.000,-/ k g$ dan merugi bila harga jual mencapai $R p 11.750$,- atau lebih rendah. Dengan demikian dapat dikatakan pembesaran ikan betutu dalam hampang dengan pemberian pakan ikan rucah atau moluska cukup toleran terhadap penurunan harga jual ikan sampai Rp10.250, dan $\mathrm{Rp} 12.000,-/ \mathrm{kg}$ atau lebih kurang setengah dari harga normal yang berlaku saat ini $(\mathrm{Rp} 25.000,-/ \mathrm{kg})$.

\section{Jangka Waktu Pengemb' ،ian Investasi}

Jangka waktu pengembalian investasi pemeliharaan ikan betutu sistem hampang masing. masing berdasarkan pemberian pakan yang berbeda disajikan pada Table 5 .

Table 5. Pay back periods of sand goby pen culture system.

\begin{tabular}{lcc}
\hline \multirow{2}{*}{ Kind of feed } & \multicolumn{2}{c}{ Pay back period } \\
\cline { 2 - 3 } & Month & Period of culture \\
\hline Trash fish & 6,5 & 1,08 \\
Mollusc & 7,9 & 1,31 \\
\hline
\end{tabular}

Table 5 menunjukkan bahwa jangka waktu pengembalian investasi usaha pembesaran ikan betutu dalam hampang adalah selama 6,5 bulan atau 1,08 periode pemeliharaan jika menggunakan pakan ikan rucah. Waktu ini lebih cepat dibanding bila menggunakan pakan moluska, yaitu 7,9 bulan atau 1,31 priode pemeliharaan. Dengan kata lain setelah sekitar 2 kali periode tanam, investasi sudah dapat dikembalikan secara total.

\section{KESIMPULAN}

Ditinjau dari aspek ekonomi usaha pembesaran ikan betutu dalam hampang pada skala pene. litian ini cukup menguntungkan dan layak baik menggunakan pakan ikan rucah atau pakan moluska. Skala usaha dan jangka waktu pemeliharaan masih dapat ditingkatkan, disesuaikan dengan kemampuan investasi, tenaga dan potensi lahan guna mendapatkan hasil usaha yang lebih besar dari pada skala usaha dalam penelitian ini.

Keuntungan yang didapat pada skala usaha penelitian ini, yakni Rp1.061.500,./6 bulan bila menggunakan pakan ikan rucah dan Rp802.000,per 6 bulan bila menggunakan pakan moluska. Efisiensi usaha cukup baik, yaitu 2,44 pada perlakuan pakan ikan rucah dan 2,11 pada perlakuan pakan moluska.

Tingkat rentabilitas adalah $157,5 \%$ pada perlakuan pakan ikan rucah dan $124 \%$ pada perlakuan pakan moluska. Di samping itu, jika terjadi penurunan harga jual ikan nilai titik impas dapat bertahan sampai harga jual $R \mathbf{p} 10.250,-/ \mathbf{k g}$ pada pemberian pakan ikan rucah dan Rp12.000,per kg bila menggunakan pakan moluska. Waktu pengembalian investasi paling lama 2 musim tanam. 


\section{DAFTAR PUSTAKA}

Djajadiredja, R. dan M.Yunus.1982. Budidaya ikan di Indonesia: suatu tinjauan sosial dan ekonomi. Prosiding Workshop Sosial Ekonomi Perikanan Indonesia, Puslitbang Perikanan 1982.

Gittinger, J.P. 1986. Economic analysis of agricultural projects, The Economic Development Institute, IBRD - World Bank, The Johns Hopkins University Press, Baltimore and London.

Nasution, Z. dan A.D.Utomo. 1994. Evaluasi dan prospek pengembangan budidaya beberapa jenis ikan air tawar pada berbagai sistem budidaya. Kumpulan Makalah Seminar Penyusunan, Pengolahan dan Evaluasi Hasil Penelitian Perikanan Di Perairan Umum, Sub Balitkanwar Palembang.

Nitisemito. 1991. Wawasan Kelayakan dan Evaluasi Proyek. Penerbit BUMI AKSARA Jakarta. 1991.
Sigit, S. 1979. Analisa break even. Penerbit Pendidikan Ahli adminitrasi Perusahaan, Universitas Gajah Mada, Yogyakarta.

Soeharjo, A. 1972. Analisa biaya dan pendapatan usahatani. Departemen Ilmu ilmu Sosial Ekonomi, Fakultas Pertanian, IPB, Bogor.

Widiyati, A. dan H.Djajasewaka. 1992. Pengaruh pemberian pakan buatan, pakan alami dan campuran keduanya terhadap pertumbuhan benih ikan betutu. Prosiding Seminar Hasil Penelitian Perikanan Air Tawar 1992/1993, Balitkanwar, Bogor.

Wattanutchariya, S. and T. Panayotou. 1981. The Economic of aquaculture, The case study of catfish in Thailand (Paper on Aquaculture Economic Research in Asia. in Proceed. of a workshop held in Singapore, 2 June 1981), IDRC-ICLARM. 